\title{
Hubungan Faktor Biotik dan Abiotik Terhadap Keanekaragaman Makrobentos di Hutan Mangrove Kabupaten Lombok Barat
}

\section{Nirmala Ayu Aryanti1*, Febri Arif Cahyo Wibowo', Mahidi1, Frita Kusuma Wardhani2, I Komang Tri Wijaya Kusuma ${ }^{3}$}

\author{
'Program Studi Kehutanan Fakultas Pertanian-Peternakan Universitas Muhammadiyah Malang \\ Jl. Raya Tlogomas No. 246 Tlogomas, Lowokwaru, Malang, Jawa Timur 65144 Indonesia \\ 2Departemen Konservasi Sumberdaya Hutan, Fakultas Kehutanan Universitas Gadjah Mada \\ Jl. Agro, Bulaksumur No.1, Caturtunggal, Daerah Istimewa Yogyakarta 55281 Indonesia \\ 3Pengendali Ekosistem Hutan Muda BPPIKHL Jawa Bali Nusa Tenggara, \\ JL. Bypass Ngurah Rai KM 21, Suwung Kauh Denpasar Indonesia \\ Email: nirmalaaaryanti@gmail.com
}

\begin{abstract}
The Influence of Biotic and Abiotic on Macrobenthos Diversity in West Lombok Mangrove Forest

High human activity around the coastal area will affect the mangrove ecosystem and the biota such as macrobenthos. Benthic diversity can reflect conditions of mangrove ecosystem, that slow growth and sensitive to environmental changes. This study aims to determine the influence of biotic and abiotic environments on the macrobenthos in Cendi Manik Village, Sekotong District, West Lombok Regency, West Nusa Tenggara. Data collection of macrobenthos, biotic and abiotic environments in natural and rehabilitation mangrove, then the diversity species of macrobenthos with biotic and abiotic environmental variables were analyzed multiple regression. The most dominant vegetations are Rhizophora mucronata Lam and Avicennia marina Forssk. The diversity index for macrobenthos is low ( $\left.H^{\prime} 1,207\right)$ in natural and rehabilitation mangrove. Macrobenthos between two location have high similarity with $84,6 \%$. The result of multiple regression test showed that most influencing of macrobenthos were mud thickness and brightness.
\end{abstract}

Keywords : anthropogenic, coastal, macrobenthos, mud thickness, brightness

\begin{abstract}
Abstrak
Aktivitas manusia yang tinggi sekitar kawasan pesisir akan mempengaruhi ekosistem mangrove dan biota di dalamnya seperti makrobentos. Keanekaragaman bentos dapat mampu mencerminkan kondisi ekosistem mangrove, pertumbuhan yang lambat dan sensitif terhadap perubahan lingkungan. Penelitian ini bertujuan untuk mengetahui hubungan lingkungan biotik dan abiotik terhadap makrobentos yang ada di Desa Cendi Manik Kecamatan Sekotong Kabupaten Lombok Barat Nusa Tenggara Barat. Pengumpulan data makrobentos, biotik dan abiotik lingkungan pada hutan mangrove alam dan rehabilitasi, kemudian keanekaragaman jenis makrobentos dengan variabel lingkungan biotik dan abiotik dianalisis regresi berganda. Jenis vegetasi yang paling mendominasi adalah jenis Rhizophora mucronata Lam dan Avicennia marina Forssk. Keanekaragaman jenis makrobentos termasuk dalam kategori rendah $\left(H^{\prime} 1,207\right)$ di hutan mangrove alam dan rehabilitasi. Jenis makrobentos antara dua lokasi tersebut memiliki kemiripan yang tinggi yaitu $84,6 \%$. Uji regresi berganda diperoleh variabel lingkungan yang paling berpengaruh pada keanekaragaman jenis makrobentos adalah ketebalan lumpur dan kedalaman kecerahan air.
\end{abstract}

Kata kunci : antropogenik, pesisir, makrobentos, ketebalan lumpur, kecerahan 


\section{PENDAHULUAN}

Ekosistem Mangrove Indonesia terluas di dunia, tercatat mencapai 243 jenis dengan 197 marga dan 83 suku dari 268 jenis di Asia Tenggara, dengan garis pantai yang dimiliki Indonesia sepanjang $99.093 \mathrm{~km}$ (Darajati et al., 2016). Luasan hutan mangrove mencapai 3.361.216 Ha pada tahun 2017 (Rahadian et al., 2019). Hutan mangrove merupakan ekosistem yang berada di wilayah peralihan antara daratan - batas laut, mampu menampung beragam spesies hingga menjadi tempat berkembangbiak biota laut (Eid et al., 2019). Luas hutan mangrove yang tersisa di Pulau Lombok dalam kondisi baik diperkirakan tersisa hanya 49,7\% (Mujiono, 2016). Sebagian besar kerusakan disebabkan oleh aktivitas manusia yang juga terjadi pada kawasan hutan mangrove di Desa Cendi Manik Kecamatan Sekotong Kabupaten Lombok Barat Nusa Tenggara Barat dengan adanya kegiatan usaha tambak. Aktivitas antropogenik dapat menyebabkan penurunan kualitas lingkungan biotik dan abiotik antara kawasan hutan mangrove alam dengan rehabilitasi (Susiana, 2015).

\section{Keberadaan sedimen berlumpur atau berpasir pada ekosistem mangrove merupakan rumah bagi beragam epibenthic, infauna, dan meiofaunal yang terdapat komunitas fitoplankton, zooplankton dan ikan (Kandasamy \& Bingham, 2001). Keanekaragaman jenis biota mangrove dipengaruhi oleh kondisi fisik perairan sebesar $77,20 \%$ seperti suhu, salinitas, $\mathrm{pH}$ dan kedalaman lumpur, sisanya sebesar $22,80 \%$ dipengaruhi oleh faktor lain (Latupapua, 2011).}

Bentos merupakan salah satu biota yang hidup pada ekosistem mangrove. Bentos hidup di dasar perairan atau melekat pada substrat yang keras, memiliki beberapa ukuran yaitu makrobentos dan mikrobentos (Poedjirahajoe, 2019). Komunitas bentos berperan sebagai penghalus hingga pengurai bahan organik menjadi anorganik (hara) untuk dapat digunakan kembali oleh tanaman, serta dapat digunakan sebagai indikator pulinnya ekosistem mangrove (Poedjirahajoe, 2019; Sujatmiko \& Aunurohim, 2013). Keragaman jenis bentos mampu mencerminkan kondisi ekosistem mangrove karena relatif menetap, pergerakan yang lambat dan sangat sensitif terhadap perubahan karakteristik lingkungan (Veiga et al., 2016; Farooq \& Siddiqui, 2020)

Tekanan aktivitas manusia disekitar kawasan mangrove dapat menyebabkan kerusakan ekosistem mangrove khususnya bagi biota yang hidup di dalamnya, sehingga perlu studi ekologi mangrove sebagai upaya monitoring, managemen dan konservasi. Tujuan penelitian ini untuk mengetahui hubungan faktor lingkungan biotik dan abiotik terhadap keanekaragaman makrobenthos yang ada di hutan mangrove di Desa Cendi Manik Kecamatan Sekotong Kabupaten Lombok Barat Nusa Tenggara Barat

\section{MATERI DAN METODE}

Penelitian dilaksanakan di kawasan mangrove hutan alami $(11,55 \mathrm{Ha})$ dan hutan rehabilitasi (15,55 Ha) Desa Cendi Manik, Kecamatan Sekotong, Kabupaten Lombok Barat, Nusa Tenggara Barat. Metode pengambilan data dengan purpose sampling, masing-masing lokasi hutan diletakkan nested plot pada tiap jalur dari arah daratan menuju laut. Pada tiap plot dilakukan pengambilan data lingkungan biotik dan abiotic. Data biotik yang diambil yaitu jenis dan jumlah individu vegetasi dan makrobentos. Nested plot yang digunakan yaitu $10 \times 10 \mathrm{~m}$ untuk pohon, 5x5m untuk pancang dan $2 \times 2 m$ untuk semai (Wiyanto \& Faiqoh, 2015; Ghufrona et al., 2015). Tingkat pohon mangrove jarang dijumpai diameter batang lebih dari $20 \mathrm{~cm}$ kecuali pada hutan alam di Papua, sehingga tingkat pohon umumnya antara $10-20 \mathrm{~cm}$ dengan petak ukur paling besar menggunakan $10 \times 10 \mathrm{~m}$ (Poedjirahajoe, 2019). Pengambilan data makrobentos dengan menggunakan alat jaring yang digunakan pada setiap petak ukur, dengan mengelilingi luasan petak 10×10 dan menggunakan tangan saat pengambilan makrobentos. Kemudian mengidentifikasi dan menghitung individu tiap jenis bentos yang terjaring tiap petak ukur. Data lingkungan abiotik dilakukan dengan pengukuran pada setiap petak ukur antara $\mathrm{pH}$, salinitas $(\%)$, suhu $\left({ }^{\circ} \mathrm{C}\right)$, ketebalan lumpur $(\mathrm{cm})$, kedalaman kecerahan air (cm). 
Data vegetasi tiap tingkat pertumbuhan pohon diolah untuk mengetahui jenis yang mendominasi dengan Indeks Nilai Penting (INP) dan dihitung juga kerapatannya (individu/Ha). Data makro-bentos dianalisis indeks keanekaragaman jenis menggunakan Indeks Shannon (H') dan indeks kesamaan (IS) (Magurran \& McGill, 2011)pada hutan mangrove alam dan rehabilitasi. Indeks kesamaan digunakan untuk mengetahui tingkat kemiripan makrobentos pada hutan mangrove alam dengan rehabilitasi. Menurut Barbour et al. (1987) dan Krebs (1978) nilai indeks keragaman Shannon dapat diklasifikasi beberapa kategori yaitu bila nilai $H^{\prime}$ 0-2 tergolong rendah, nilai $H^{\prime} \quad 2-3$ tergolong sedang dan nilai H' > 3 tergolong tinggi. Indeks similaritas menunjukkan tingkat kemiripan komposisi dan struktur antar komunitas dengan IS $>50 \%$ kategori similaritas tinggi dan IS $\quad<50 \%$ kategori similaritas rendah (Cahyaningrum, 2020). Untuk Mengetahui pengaruh variabel lingkungan abiotik dan biotik (kerapatan tiap tingkat pertumbuhan pohon (individu/ha)) dengan keanekaragaman jenis bentos menggunakan analisis regresi ganda (Usman \& Akbar, 2015).

\section{HASIL DAN PEMBAHASAN}

\section{Karakteristik Lingkungan Biotik dan Abiotik Hutan Mangrove Habitat Makrobentos}

Secara keseluruhan jenis tumbuhan yang ditemukan pada kawasan mangrove di Desa Cendi Manik Kecamatan Sekotong
Lombok Barat Nusa Tenggara Barat sebanyak 7 jenis. Jenis mangrove yang ditemukan antara lain Rhizophora mucronata Lam, Rhizophora stylosa Griff, Rhizophora apiculata Blume, Avicenia marina Forssk, Sonneratia casoelaris Engl, Ceriops decandra Griff, dan Excoecaria agallocha L. Pada hutan mangrove alami ditemukan tingkat pertumbuhan pohon hingga semai, sedangkan pada hutan rehabilitasi hanya terdapat tingkatan pancang dan semai. Kawasan mangrove rehabilitasi di Desa Cendi Manik pernah dilakukan penanaman oleh Kementerian Kelautan dan Perikanan Direktorat Jendral Pengelolaan Ruang Laut Balai Pengelolaan Sumberdaya Pesisir dan Laut Denpasar pada tahun 2016. Penanaman sejak tahun 2016 tersebut juga dilakukan program penyulaman setelah tahun pertama hingga sekarang, sehingga pada hutan mangrove rehabilitasi dijumpai tingkat pertumbuhan pancang dan semai. Tampak pada hutan rehabilitasi memiliki pancang dan semai yang lebih banyak dari pada hutan alam.

Jenis Rhizophoraceae merupakan jenis yang ditanam pada kegiatan rehabilitasi sehingga mendominasi pada kawasan hutan mangrove di Desa Cendi Manik Kecamatan Sekotong Lombok Barat Nusa Tenggar Barat. Berdasarkan penghitungan Indeks Nilai Penting (INP), kawasan hutan alam dan rehabilitasi pada semua tingkatan pertumbuhan yang ditemukan jenis dengan

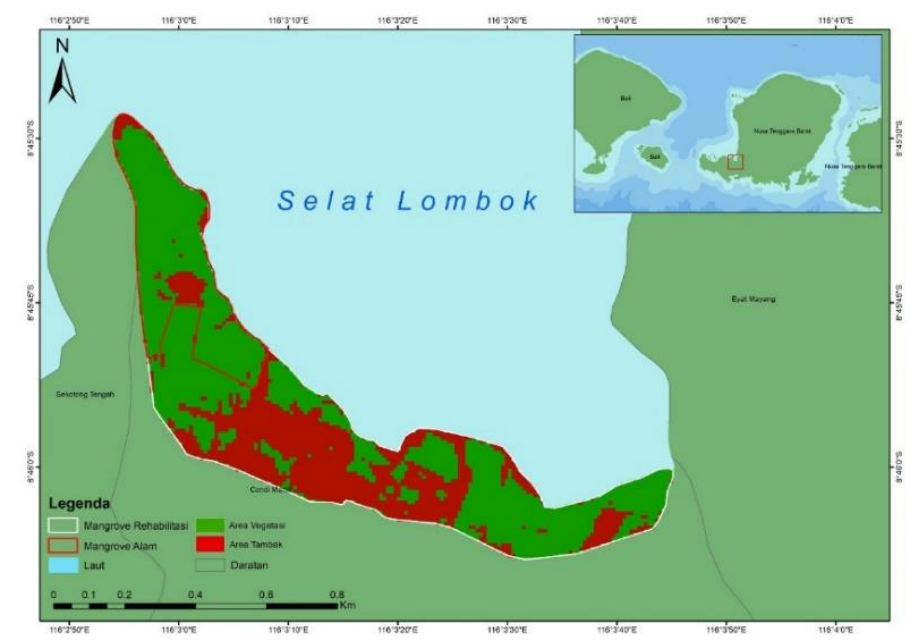

Gambar 1. Peta kawasan hutan alami dan hutan rehabilitasi mangrove Desa Cendi Manik, Kecamatan Sekotong, Kabupaten Lombok Barat, Nusa Tenggara Barat. 
Tabel 1. INP Pada Tiap Tingkat Pertumbuhan Pohon Hutan Mangrove Alami di Desa Cendi Manik Kecamatan Sekotong Lombok Barat Nusa Tenggar Barat

\begin{tabular}{|c|c|c|c|c|c|c|}
\hline \multicolumn{7}{|c|}{ Tingkat Semai } \\
\hline No & Jenis Mangrove & $\mathrm{KR} \%$ & \multicolumn{2}{|r|}{ FR\% } & \multicolumn{2}{|r|}{ INP } \\
\hline 1 & Rhizophora mucronata Lam & 99,23 & \multicolumn{2}{|r|}{73,53} & \multicolumn{2}{|r|}{173} \\
\hline 2 & Avicennia marina Forssk & 0,77 & \multicolumn{2}{|r|}{26,47} & \multicolumn{2}{|r|}{27} \\
\hline & Jumlah & 100 & \multicolumn{2}{|r|}{100} & \multicolumn{2}{|r|}{200} \\
\hline \multicolumn{7}{|c|}{ Tingkat Pancang } \\
\hline No & Jenis Mangrove & $\mathrm{KR} \%$ & \multicolumn{2}{|r|}{$\mathrm{FR} \%$} & $\mathrm{DR} \%$ & INP \\
\hline 1 & Rhizophora mucronata Lam & 98,98 & \multicolumn{2}{|r|}{71,43} & 99,21 & 270 \\
\hline 2 & Avicennia marina Forssk & 1,02 & \multicolumn{2}{|r|}{28,57} & 0,79 & 30 \\
\hline & Jumlah & 100 & \multicolumn{2}{|r|}{100} & 100 & 300 \\
\hline \multicolumn{7}{|c|}{ Tingkat Pohon } \\
\hline No & Jenis Mangrove & $\mathrm{KR} \%$ & DR\% & $\mathrm{FR} \%$ & & INP \\
\hline 1 & Rhizophora mucronata Lam & 40,28 & 40,99 & 32,73 & & 114 \\
\hline 2 & Avicennia marina Forssk & 20,83 & 18,66 & 23,64 & & 63 \\
\hline 3 & Rhizophora stylosa Griff & 13,19 & 14,46 & 12,72 & & 40 \\
\hline 4 & Rhizophora apiculate Blume & 6,25 & 9,05 & 7,27 & & 23 \\
\hline 5 & Sonneratia caseolaris Engl & 12,5 & 10,28 & 12,72 & & 36 \\
\hline \multirow[t]{2}{*}{6} & Excoecaria agallocha $\mathrm{L}$ & 6,94 & 6,56 & 10,91 & & 24 \\
\hline & Jumlah & 100 & 100 & 100 & & 300 \\
\hline
\end{tabular}

nilai INP tertinggi adalah Rhizophora mucronata Lam. Jenis tumbuhan Rhizophora mucronata Lam merupakan jenis yang mudah beradaptasi dengan lingkungan (Hidayatullah \& Pujiono, 2014). Penelitian kondisi hutan mangrove di Kabupaten Lombok Timur dan Lombok tengah oleh Mujiono (2016) didominasi oleh jenis Rhizophoraceae dan Sonneratiaceae. Jenis Avicennia marina Forssk nilai INP tertinggi berikutnya, hal tersebut dikarenakan jenis Acanthaceae menyukai genangan dan mampu hidup pada daerah yang dekat dekat dengan laut. Jenis Rhizophora mucronata Lam. dan Avicennia marina Forssk mendominasi pada lokasi penelitian Descasari et al., (2016) karena mampu hidup pada substrat berlumpur dan berpasir. Kemampuan regenerasi yang sangat baik untuk jenis Rhizophora mucronata Lam., serta kisaran toleransi yang luas suhu dan salinitas untuk jenis Avicennia marina
Forssk. menyebabkan kedua jenis tersebut mampu menjadi dominan.

Keberadaan vegetasi penting bagi ekosistem kawasan mangrove, potensi perakaran mangrove mampu mengikat substrat lumpur sehingga dapat meningkatkan ketebalan lumpur (Poedjirahajoe et al., 2017). Keberadaan tingkat pertumbuhan pohon dapat menjadi indukan sehingga menjamin proses regenerasi vegetasi di kawasan mangrove, sehingga potensi pakan bagi bentos terjamin. Keberadaan tegakan pohon pada hutan mangrove dibutuhkan oleh biota yang di dasar perairan, seperti kepiting yang mengkonsumsi seresah dan membuat liang pada substrat yang lunak (Poedjirahajoe, 2019). Pada kawasan mangrove rehabilitasi dan alami ditemukan jenis kepiting family Portunidae (Scylla paramamosain (Estampador, 1950)) dan Portunus trituberculatus (Rathbun, 1902)), Sesarmidae 
(Episesarma sp. dan Episesarma singaporense (Tweedie, 1936)) dan Ocypodidae (Uca triangularis (Milne-Edwards A, 1873) dan Uca dusumeiri (H. Milne Edwards, 1852)). Jenis tersebut dapat ditemukan memanjat di batang dan akar tanaman pada daerah lantai mangrove, pinggiran mangrove hingga bekas tebangan mangrove (Sujatmiko \& Aunurohim, 2014; Redjeki et al., 2017).

Terdapat 17 Jenis makrobentos yang ditemukan pada kawasan mangrove di Desa Cendi Manik Kecamatan Sekotong Lombok
Barat Nusa Tenggara Barat. Sebanyak 15 jenis di hutan alam dan 14 jenis di hutan rehabilitasi mangrove. Namun ada jenis-jenis yang hanya ditemukan di salah satu komunitas hutan mangrove saja seperti Lutraria lutraria (Linnaeus, 1758) dan Episesarma sp. ditemukan di hutan alam, sedangkan Littorina scabra L. dan Calliostoma olssoni (Bayer, 1971) hanya ditemukan di hutan rehabilitasi. Hasil penghitungan indeks keanekaragaman jenis (H') makrobentos baik di hutan alam dan rehabilitasi yaitu 1,207 masuk dalam kategori rendah.

Tabel 2. INP Pada Tiap Tingkat Pertumbuhan Pohon Hutan Mangrove Rehabilitasi di Desa Cendi Manik Kecamatan Sekotong Lombok Barat Nusa Tenggar Barat

\begin{tabular}{|c|c|c|c|c|c|}
\hline \multicolumn{6}{|c|}{ Tingkat Pancang } \\
\hline No & Jenis Mangrove & $\mathrm{KR} \%$ & FR\% & $\mathrm{DR} \%$ & INP \\
\hline 1 & Rhizophora mucronata Lam & 29,44 & 24,56 & 36,32 & 90 \\
\hline 2 & Avicennia marina Forssk & 22,18 & 21,05 & 17,93 & 61 \\
\hline 3 & Rhizophora stylosa Griff & 8,87 & 8,77 & 6,37 & 24 \\
\hline 4 & Rhizophora apiculataBlume & 16,13 & 14,05 & 11,09 & 41 \\
\hline 5 & Sonneratia caseolaris Engl & 8,87 & 12,28 & 13,99 & 35 \\
\hline 6 & Ceriops decandra Griff & 6,05 & 8,77 & 5,90 & 21 \\
\hline 7 & Excoecaria agallocha L & 8,47 & 10,53 & 8,40 & 27 \\
\hline & Jumlah & 100 & 100 & 100 & 300 \\
\hline \multicolumn{6}{|c|}{ Tingkat Semai } \\
\hline No & Jenis Mangrove & & $\mathrm{KR} \%$ & $\mathrm{FR \%}$ & INP \\
\hline 1 & Rhizophora mucronata Lam & & 34,81 & 28,81 & 64 \\
\hline 2 & Avicennia marina Forssk & & 19,26 & 20,34 & 40 \\
\hline 3 & Rhizophora stylosa Griff & & 5,93 & 8,47 & 14 \\
\hline 4 & Rhizophora apiculate Blume & & 10,37 & 13,56 & 24 \\
\hline 5 & Sonneratia caseolaris Engl & & 14,32 & 11,86 & 26 \\
\hline 6 & Ceriops decandra Griff & & 6,42 & 6,78 & 13 \\
\hline 7 & Excoecaria agallocha L & & 8,89 & 10,17 & 19,06 \\
\hline \multicolumn{3}{|c|}{ Jumlah } & 100 & 100 & 200 \\
\hline
\end{tabular}

Tabel 3. Karekteristik lingkungan biotik hutan mangrove di Desa Cendi Manik Kecamatan Sekotong Lombok Barat Nusa Tenggar Barat

\begin{tabular}{lcccc}
\hline \multirow{2}{*}{\multicolumn{1}{c}{ Variabel }} & \multicolumn{2}{c}{ Hutan Alam } & \multicolumn{2}{c}{ Hutan Rehabilitasi } \\
\cline { 2 - 5 } & Jumlah & Rata-rata & Jumlah & Rata-rata \\
\hline Kepadatan pohon (ind/Ha) & $4-36$ & 23 & 0 & 0 \\
Kepadatan pancang (ind/Ha) & $64-272$ & 159 & $0-920$ & 318 \\
Kepadatan semai (ind/Ha) & $600-4400$ & 1620 & $0-5625$ & 3237,5 \\
Jumlah individu bentos & $11-37$ & 25 & $14-36$ & 25 \\
Jumlah jenis bentos & $2-6$ & 4 & $3-4$ & 4 \\
H' benthos & $0,59-1,59$ & - & $0,96-1,38$ & - \\
\hline
\end{tabular}



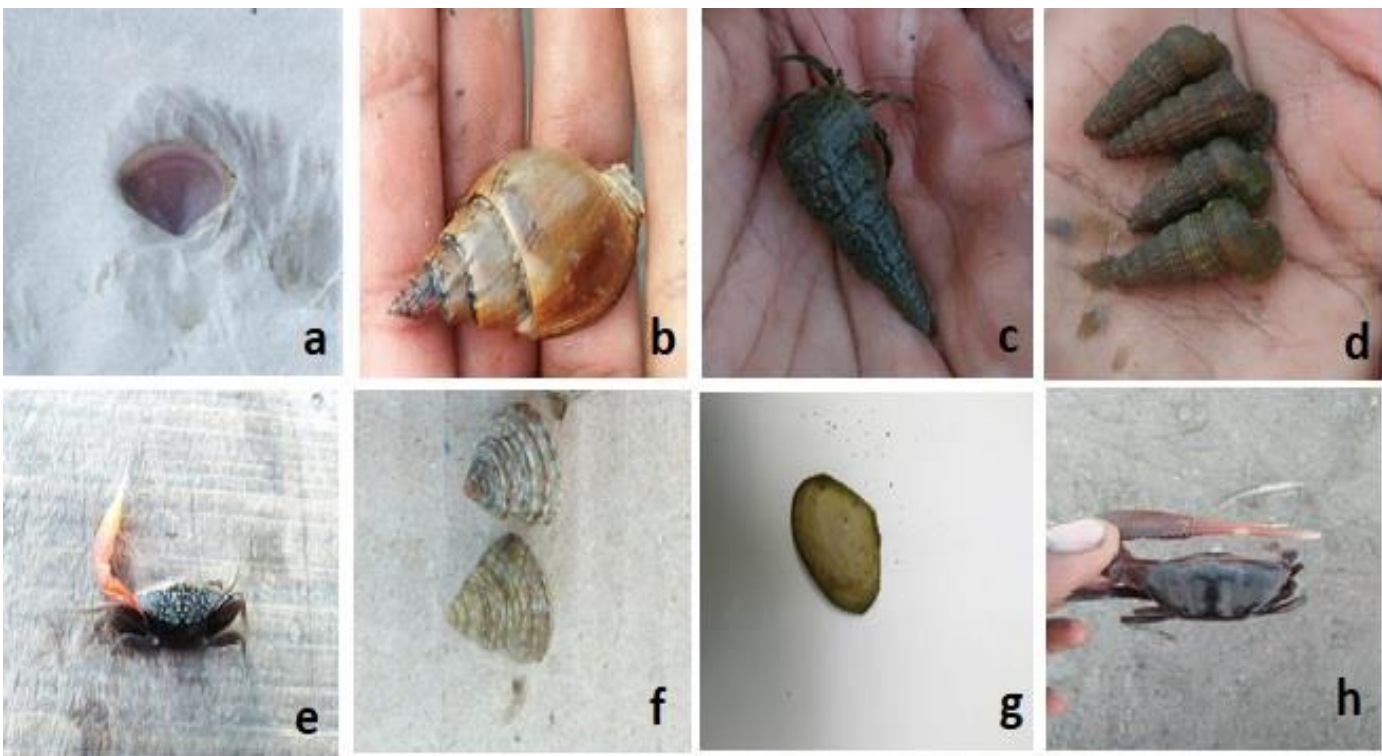

Gambar 2. Jenis makrobentos yang mendominasi pada hutan mangrove Desa Cendi Manik Kecamatan Sekotong Lombok Barat Nusa Tenggar Barat (Keterangan: a). Lutraria Iutraria (Linnaeus, 1758); b). Strombus urceus (Linnaeus, 1758); c). Rhinoclavis articulata (A.Adams \& Reeve, 1850); d). Cerithidae quadrata (Sowerby, 1866); e). Uca triangularis (Milne-Edwards A, 1873); f). Calliostroma olssoni (Linnaeus, 1758); g). Nucula sulcate (Bronn, 1831); h). Uca dusumeiri (H. Milne Edwards, 1852)

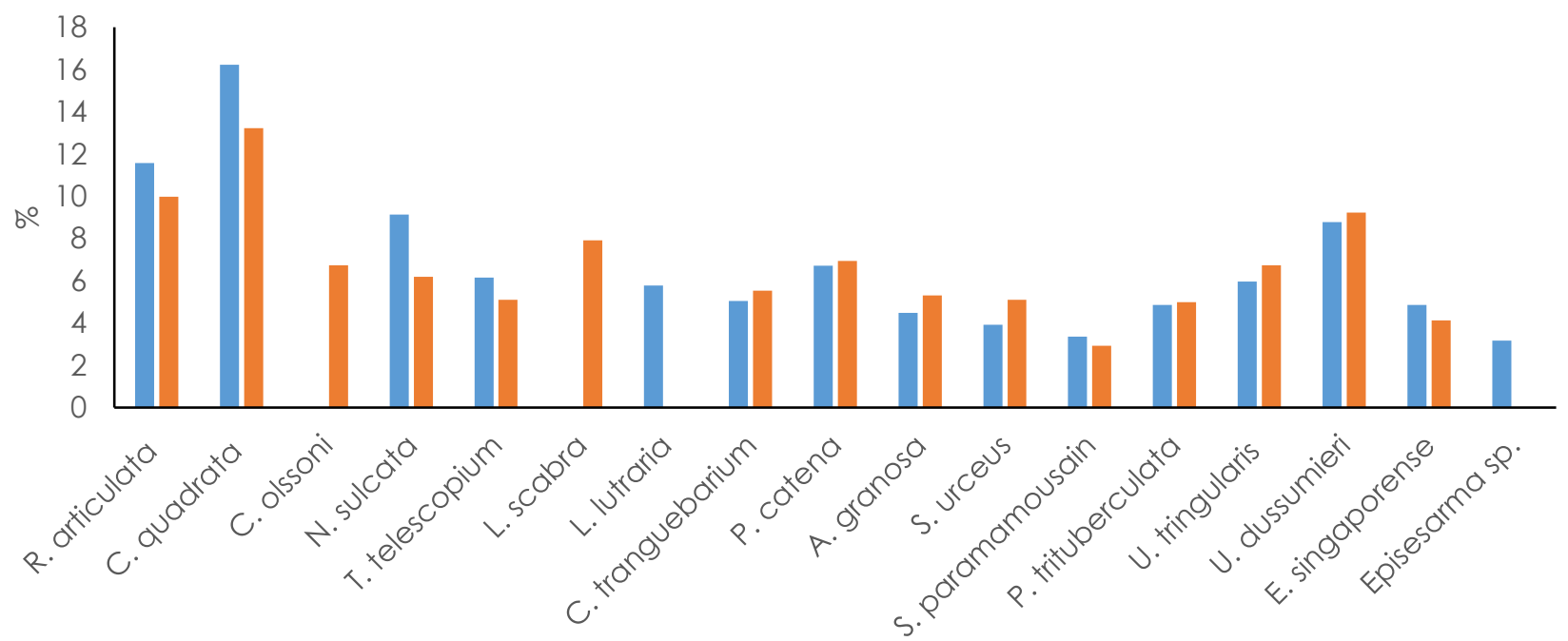

- Frekuensi Relatif Makrobentos Mangrove Alami Erekuensi Relatif Makrobentos Mangrove Rehabilitasi

Gambar 3. Frekuensi Relatif Jenis Makrobentos di Desa Cendi Manik Kecamatan Sekotong Lombok Barat Nusa Tenggara Barat

\section{Hubungan Faktor Lingkungan Biotik Dan Abiotik Terhadap Makrobenthos}

Rendahnya nilai keanekaragaman jenis makrobentos disebabkan karena pada hutan alam dan rehabilitasi mangrove ratarata ditemukan 4 jenis makrobentos dan adanya dominasi suatu jenis. Penelitian juga dilakukan oleh Salim et al., (2019) pada hutan mangrove alam di Kawasan Konservasi Mangrove dan Bekantan Kota Tarakan memiliki jenis makrobentos yang sedikit yaitu 7 jenis. Dijelaskan pula bahwa, keberadaan makrobentos tersebut tidak dipengaruhi oleh 
kerapatan tegakan vegetasi melainkan dari variabel lain seperti sedimen, ketersediaan cahaya matahari dan bahan organik. Keanekaragaman dan jumlah jenis makrobentos yang rendah mengindikasikan bahwa sedikitnya jenis makrobentos yang toleran (Putri et al., 2015). Pada Desa Cendi Manik, hutan rehabilitasi alami didominasi oleh jenis Uca dussumieri (H. Milne Edwards, 1852), Cerithidae quadrata (Sowerby, 1866), Nucula sulcate (Bronn, 1831), dan Rhinoclavis articulata (A. Adams \& Reeve, 1850). Pada hutan rehabilitasi mangrove didominasi oleh Cerithidae quadrata (Sowerby, 1866), Rhinoclavis articulata (A.Adams \& Reeve, 1850), Littorina scabra L., dan Uca dussumieri (H. Milne Edwards, 1852). Hutan mangrove di Desa Cendi Manik didominasi jenis Rhizophora, menurut putri et al., (2015) berkorelasi positif dengan jenis makrobentos, untuk jenis Crustacea bahkan mampu memengaruhi struktur komunitas mangrove karena merupakan predator benih mangrove.

Tingkat kesamaan komposisi jenis antara makrobentos di hutan alam dan rehabilitasi mangrove diperoleh indeks similaritas $84,6 \%$ mengindikasikan bahwa komposisi jenis penyusun komunitas tersebut relative sama.
Indeks similaritas menunjukkan tingkat kemiripan komposisi dan struktur antar komunitas dengan IS $>50 \%$ kategori similaritas tinggi dan IS $<50 \%$ kategori similaritas rendah (Cahyaningrum, 2020). Hal tersebut dapat disebabkan oleh lokasi antara hutan alam dan rehabilitasi mangrove sangat bersebelahan. Jenis vegetasi yang didominasi oleh Rizhophora pada hutan mangrove alam dan rehabilitasi menjadi sumber pakan beberapa jenis makrobentos dan kerapatan vegetasi bukan menjadi variabel yang memengaruhi keberadaan makrobentos. Kondisi lingkungan mikro yang relative homogen antara hutan mangrove alami dan rehabilitasi (hasil nilai rata-rata pada Tabel2), menjadi tempat hidup individu jenis yang sama. Makrobentos tersebut pada akhirnya secara alami telah mampu mengembangkan mekanisme adaptasi dan toleransi terhadap habitatnya (Setiadi, 2005).

\section{Hubungan Faktor Lingkungan Biotik dan Abiotik dengan Keanekargaman Jenis Makrobentos}

Hasil uji regresi hubungan kondisi lingkungan terhadap keanekaragaman bentos di Desa Cendi Manik Kecamatan Sekotong Lombok

Tabel 4. Karekteristik lingkungan abiotik hutan Mangrove di Desa Cendi Manik Kecamatan Sekotong Lombok Barat Nusa Tenggar Barat

\begin{tabular}{lcccc}
\hline \multirow{2}{*}{ Variabel } & \multicolumn{2}{c}{ Hutan Alam } & \multicolumn{2}{c}{ Hutan Rehabilitasi } \\
\cline { 2 - 5 } & Jumlah & Rata-rata & Jumlah & Rata-rata \\
\hline Suhu $\left({ }^{\circ} \mathrm{C}\right)$ & $25-28$ & 26,44 & $25-30$ & 27,65 \\
$\mathrm{pH}$ & $5-7$ & 6,16 & $5-7$ & 6,2 \\
Salinitas $(\%)$ & $30-40$ & 35,2 & $30-40$ & 36,82 \\
Ketebalan lumpur (cm) & $15-54$ & 34 & $15-47$ & 33,45 \\
Kedalaman kecerahan air(cm) & $20-35$ & 25,04 & $15-36$ & 25,15 \\
\hline
\end{tabular}

Tabel 5. Ringkasan Hasil Analisis Regresi Linier Berganda Hutan Alam Mangrove

\begin{tabular}{cc}
\hline Variabel independen & Sig.(1-tailed) \\
\hline Ketebalan lumpur (X1) & 0,041 \\
Kedalaman kecerahan air (X2) & 0,027 \\
Suhu (X3) & 0,468 \\
PH (X4) & 0,259 \\
Salinitas (X5) & 0,07 \\
Kepadatan Pancang (X6) & 0,305 \\
Kepadatan Semai (X7) & 0,170 \\
\hline
\end{tabular}

Keterangan : $R=0,693, R^{2}=0,48 ; F=3,297$, Sig. $=0,001$ 
Barat Nusa Tenggara Barat. Diperoleh keberadaan bentos dipengaruhi oleh beberapa faktor lingkungan yaitu ketebalan lumpur, dan kedalaman kecerahan air. Tujuh variabel independent (bebas) setelah dianalisis hanya dua variabel bebas dengan nilai probalitas atau sig.(2-tailed) lebih kecil dari 0,05 yang berarti ada korelasi yang signifikan. Nilai R semakin mendekati 1 korelasi semakin kuat (Santoso, 2014), hasil perhitungan diperoleh 0,693 menunjukkan bahwa korelasi/hubungan antara keanekaragaman jenis makrobentos dengan dua variabel independennya adalah kuat.

Kontribusi variabel jumlah semai, salinitas dan kecerahan air terhadap keanekaragaman jenis makrobentos diketahui dengan koefisien determinasi atau R-squared yaitu 0,48 atau 48 $\%$. Pengaruh variabel tersebut terhadap perubahan variabel keanekaragaman jenis bentos sebesar $48 \%$ dan $52 \%$ dipengaruhi oleh variabel yang lain. Besar nilai $F$ hitung adalah 3,297 dengan signifikansi 0,001 menunjukan dua variabel tersebut secara bersama-sama dapat berpengaruh terhadap keanekaragaman jenis bentos. Diperkuat dengan intrepetasi persamaan regresi yaitu :

$$
Y=0,387-0,004 \times 1-0,002 \times 2
$$

Persamaan yang diperoleh menunjukkan bahwa keanekaragaman jenis makrobentos dipengaruhi oleh ketebalan lumpur dan kedalaman kecerahan air. Pada beberapa penelitian ditemukan struktur komunitas makrobentos tidak dipengaruhi oleh kepadatan vegetasinya, namun lebih pada kondisi lingkungan sekitar yaitu pasang surut, ketersediaan bahan organik, karakteristik sedimen dan ketersediaan cahaya matahari (Lee, 2008; Salim et al., 2019).

Hutan mangrove alam yang tersisa di Desa Cendi Manik Kecamatan Sekotong Lombok Barat Nusa Tenggar Barat masih terjadi pembukaan lahan menjadi tambak dan sekitar ekosistem pesisir terus terjadi pembukaan lahan menjadi area terbangun. Secara tidak langsung dapat menurunkan kualitas lingkungan pada ekosistem mangrove. Pengembangan tanah oleh aktivitas manusia menjadi lahan pertanian dan industri memengaruhi tanah secara langsung dengan perubahan masukan hara, irigasi, perubahan tanah mikro dan peningkatan erosi (Chapin et al., 2011). Percepatan perubahan lingkungan akibat erosi membuat ketidak seimbangan neraca sedimen. Hubungan biofisik antara hulu dan hilir, erosi yang terjadi di hulu melalui aliran sungai akan meningkatkan masukan sedimen dengan mengalir dan bermuara di kawasan pantai (seperti padang lamun, mangrove, gumuk pasir) (Astjario \& Astawa, 2007). Kondisi tersebut membuat terbentuknya delta (tanah timbul) pada kawasan pesisir akibat menumpuknya sedimentasi. Vegetasi mangrove akan tergantikan oleh vegetasi daratan karena berkurangnya penggenangan oleh pasang surut laut. Kematian vegetasi mangrove akibat perakaran tertutup oleh sedimen sehingga menurunnya pertukaran udara pada system perakaran lentisel di akar, menunjukkan bahwa kemampuan hutan mangrove menerima sedimen sangat terbatas (Ewel et al., 1998). Keberadaan vegetasi mangrove sendiri secara langsung dan tidak langsung dibutuhkan bagi bentos sebagai sumber pakan dan disembunyikan dalam tanah menjadi materi hara bagi ekosistem mangrove sendiri (Poedjirahajoe, 2019). Kematian mangrove berpengaruh terhadap nekton, benthos dan biota lainnya, karena keberadaan biota tersebut ditentukan oleh kondisi fisik kimia dan komunitas mangrove (Ernawati et al., 2013).

Kedalaman kecerahan air terhadap keanekaragaman jenis makrobentos berbanding terbalik, hal tersebut menunjukkan semakin dalam perairan maka pancaran sinar matahari sampai ke dasar perairan makin berkurang. Kecenderungan menurunnya jenis organisme bentik meiofauna hingga megabentos seiring berkurangnya pasokan cahaya matahari dan bertambahnya kedalaman perairan (Alongi, 1992). Serapan matahari yang masuk pada ekosistem rendah menyebabkan penurunan produktivitas pada ekosistem perairan. Oksigen terlarut yang dihasilkan oleh aktivitas fotosintesis fitoplankton, sehingga menyediakan oksigen dan mempengaruhi keanekara-gaman jenis jenis biota perairan yang lain (Cheung et al., 2018). 
Ekosistem mangrove di Desa Cendi Manik Kecamatan Sekotong Lombok Barat Nusa Tenggara Barat berperan sebagai habitat biota perairan di dalamnya. Meningkatnya alih fungsi tutupan Iahan bervegetasi di daratan dan pesisir menjadi lahan terbangun, menyebabkan menurunnya kondisi lingkungan biotik dan abiotik yang sesuai bagi biota yang hidup di hutan mangrove. Riset ini dapat menjadi bahan pertimbangan pengelola untuk menentukan kebijakan pengelolaan yang berkelanjutan. Bersama mengajak masyarakat berpartisipasi dalam mengelola kawasan yang tidak hanya mementingkan fungsi ekonomi dan sosial budaya saja namun juga tetap menjaga fungsi lingkungan.

\section{KESIMPULAN}

Vegetasi mangrove keseluruhan didominasi oleh jenis Rhizophora mucronata Lam. Makrobentos yang ada di hutan mangrove alam dan rehabilitasi Desa Cendi Manik Kecamatan Sekotong Lombok Barat Nusa Tenggar Barat memiliki kemiripan yang tinggi (IS $=84,6 \%$ ) dan keanekaragaman jenis rendah $\left(H^{\prime}=0,59-1,59\right)$. Keanekaragaman jenis makrobentos tersebut dipengaruhi oleh ketebalan lumpur dan kedalaman kecerahan air. Perlunya penelitian lanjutan mengenai ekosistem mangrove dan organisme tidak hanya makrobenthos namun juga mikrobenthos secara periodik.

\section{UCAPAN TERIMA KASIH}

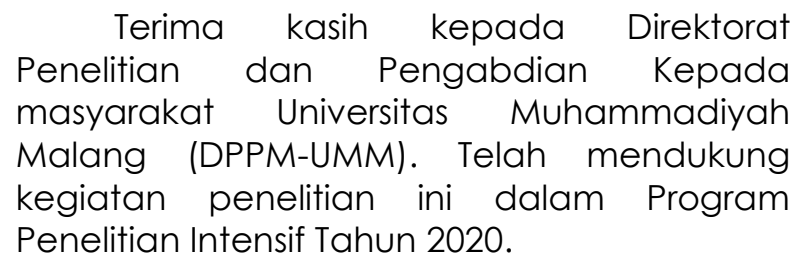

\section{DAFTAR PUSTAKA}

Alongi, D.M. 1992. Bathymetric patterns of deep-sea benthic communities from bathyal to abyssal depths in the western South Pacific (Solomon and Coral Seas). Deep-Sea Research, 39(3/4):549-565.

Astjario, P., \& Astawa, N. 2007. Proses Pertumbuhan Delta Baru Sungai Cimanuk Hingga Tahun 2002, Di Pantai Timur
Kabupaten Indramayu, Jawa Barat. Jurnal Geologi Kelautan, 5(3):109-121. doi : 10.32693/jgk.5.3.2007.139

Cahyaningrum, D.C. 2020. The Influence of Paddy Fields toward The Seasonal Herbaceous Wetland Ecosystem in Rawa Pening Lake. Jurnal Biologi Tropis, 20(2):256-262.

Chapin III, F.S., Matson, P.A., \& Vitousek, P.M. 2011. Principles of Terrestrial Ecosystem Ecology. Springer New.

Cheung, W.W., Bruggeman, J., \& Butenschön, M. 2018. Projected changes in global and national potential marine fisheries catch under climate change scenarios in the twenty-first century. In M. Barange, T. Bahri, M. Beveridge, Malcolm C, K. L. Cochrane, S. Funge-Smith, \& F. Poulain (Eds.), Impacts of climate change on fisheries and aquaculture: synthesis of current knowledge, adaptation and mitigation options, 627:63-86

Darajati, W., Pratiwi, S., Herwinda, E Rahardiansyah, A.D Nalang, V., Nooryanto, B., Rahajoe, J., Ubaidillah, R., Maryanto, I., Kurniawan, R., Prasetyo, T., Rahim, A., Jefferson, J., \& Hakim, F. 2016. Indonesian Biodiversity Strategy and Action Plan (IBSAP) 2015-2020. BAPPENAS.

Descasari, R., Setyobudiandi, I., \& Affandi, R. 2016. Keterkaitan ekosistem mangrove dengan keanekaragaman ikan di Pabean llir dan Pagirikan, Kabupaten Indramayu, Jawa Barat. Bonorowo Wetlands, 6(1):43-58. doi : 10.13057/ bonorowo/w060104

Eid, E. M., Arshad, M., Shaltout, K. H., El-sheikh, M. A., Alfarhan, A. H., Picó, Y., \& Barcelo, D. 2019. Effect of the conversion of mangroves into shrimp farms on carbon stock in the sediment along the southern Red Sea coast, Saudi Arabia. Environmental Research, 176:p108536. doi : 10.1016/j.envres.2019.108536

Ernawati, S., Niartiningsih, A., Nessa, M. N., \& Omar, S.B.A. 2013. Suksesi Makrozoobentos di Hutan Mangrove Alami dan Rehabilitasi di Kabupaten Sinjai Sulawesi Selatan. Bionature, 14(1):49-60.

Ewel, K.C., Twilley, R.R., \& Ong, J.E. 1998. Different kinds of mangrove forests provide different goods and services. Global Ecology and Biogeography Letters, 7(1):83-94. doi : 10.2307/2997700 
Farooq, S., \& Siddiqui, P.J.A. 2020. Assessment of three mangrove forest systems for future management through benthic community structure receiving anthropogenic influences. Ocean and Coastal Management, 190: p105162. doi : 10.1016/j.ocecoaman. 2020.105162

Ghufrona, R. R., Kusmana, C., \& Rusdiana, O. 2015. Species Composition and Mangrove Forest Structure in Pulau Sebuku, South Kalimantan. Jurnal Silvikultur Tropika, 06(1):15-26.

Hidayatullah, M., \& Pujiono, E. 2014. Struktur Dan Komposisi Jenis Hutan Mangrove Di Golo Sepang - Kecamatan Boleng Kabupaten Manggarai Barat. Jurnal Penelitian Kehutanan Wallacea, 3(2):151162.

Kandasamy, K., \& Bingham, B. L. (2001). Biology of Mangroves and Mangrove Ecosystems. Advances In Marine Biology, 40:81-251. doi : 10.1016/S0065-2881(01)40003-4

Latupapua, M.J.J. 2011. Keanekaragaman Jenis Nekton di Mangrove Kawasan Segoro Anak Taman Nasional Alas Purwo. Jurnal Agroforestri, 6(2):81-91.

Lee, S.Y. 2008. Mangrove macrobenthos: Assemblages, services, and linkages. Journal of Sea Research, 59:16-29. doi: 10.1016/j.seares.2007.05.002

Magurran, A.E., \& McGill, B.J. 2011. Biological Diversity: Frontiers in Measurement and Assessment (USA (ed.)). Oxford University Press.

Mujiono, N. 2016. Gastropoda Mangrove dari Pulau Lombok, Nusa Tenggara Barat. Oseanologi Dan Limnologi Di Indonesia, 1 (3):39. doi : 10.14203/oldi.2016.v1i3.55

Poedjirahajoe, E. 2019. Ekosistem Mangrove Karakteristik, Fungsi dan Dinamikanya. Gosyen Publishing.

Poedjirahajoe, E., Marsono, D., \& Wardhani, F. K. 2017. Penggunaan Principal Component Analysis dalam Distribusi Spasial Vegetasi Mangrove di Pantai Utara Pemalang. Jurnal Ilmu Kehutanan, 1 1:29-42.

Putri, L., Yulianda, F., \& Wardiatno, Y. 2015. Pola zonasi mangrove dan asosiasi makrozoobentos di wilayah Pantai Indah Kapuk, Jakarta. Bonorowo Wetlands, 5(1): 29-43. doi : 10.13057/bonorowo/w050104
Rahadian, A., Prasetyo, L.B., Setiawan, Y., \& Wikantika, K. 2019. Tinjauan Historis Data dan Informasi Luas Mangrove Indonesia. Media Konservasi, 24(2):163-178, doi: 10.29243/medkon.24.2.163-178

Redjeki, S., Arif, M., Hartati, R., \& Pinandita, K. 2017. Kepadatan Dan Persebaran Kepiting (Brachyura) Di Ekosistem Hutan Mangrove Segara Anakan Cilacap. Jurnal Kelautan Tropis, 20(3):131-139.

Salim, G., Rachmawani, D., \& Agustianisa, R. 2019. Hubungan Kerapatan Mangrove Dengan Kelimpahan Gastropoda Di Kawasan Konservasi Mangrove Dan Bekantan (KKMB) Kota Tarakan. Jurnal Harpodon Borneo, 12(1):9-19

Santoso, S. 2014. Statistik Parametrik Konsep dan Aplikasi dengan SPSS. PT Alex Media Komputindo.

Setiadi, D. 2005. Keanekaragaman Spesies Tingkat Pohon di Taman Wisata Alam Ruteng, Nusa Tenggara Timur. Biodiversitas, 6(2):1 18-122. doi: 10.13057/biodiv/d060210

Sujatmiko, B.K., \& Aunurohim. 2013. Studi Distribusi Makrofauna Benthos Di Zonasi Mangrove Pulau Poteran, Madura, Jawa Timur. Jurnal Sains Dan Seni Pomits, 2(1):1-5.

Susiana. 2015. Analisis Kualitas Air Ekosistem Mangrove Di Estuari Perancak, Bali. AGRIKAN Jurnal Ilmiah Agribinis Dan Perikanan, 8(1):1-8.

Usman, H., \& Akbar, P.S. 2015. Pengantar Statistik. PT Bumi Aksara.

Veiga, P., Torres, A.C., Aneiros, F., Sousa-pinto, I., Troncoso, J.S., \& Rubal, M. 201. Consistent patterns of variation in macrobenthic assemblages and environ-mental variables over multiple spatial scales using taxonomic and functional approaches Marine Environmental Research Consistent patterns of variation in macrobenthic assemblages and. Marine Environmental Research, 120:191-201. doi: 10.1016/j.ma renvres.2016.08.011

Wiyanto, D.B., \& Faiqoh, E. 2015. Analisis vegetasi dan struktur komunitas Mangrove Di Teluk Benoa, Bali. Journal of Marine and Aquatic Sciences, 1:1-7. 